\title{
KONTRIBUSI USAHATANI KELAPA TERHADAP PENDAPATAN KELUARGA DI DESA KLABAT KECAMATAN DIMEMBE KABUPATEN MINAHASA UTARA
}

\author{
Nofhita Mamentiwalo \\ Gene Henfried Meyer Kapantow \\ Elsje Pauline Manginsela
}

\begin{tabular}{ll}
\hline Naskah diterima melalui Website Jurnal Ilmiah agrisosioekonomi@unsrat.ac.id & : Sabtu, 20 April 2019 \\
Disetujui diterbitkan & : Jumat, 25 April 2019 \\
\hline
\end{tabular}

\begin{abstract}
This study aims to find out: 1) The amount of average income of coconut farmers per quarter, 2) The amount of contribution of coconut farming to family income per quarter. Data collection in this study was conducted from October to November 2018 in Klabat Village, Dimembe District, North Minahasa Regency. The method used is the survey method, using primary data and secondary data. Primary data was obtained through direct interviews with 25 coconut farmers and one person from the Klabat Village based on a list of questions that had been prepared previously. Secondary data in this study were sourced from local bookstores, and the internet through Google Scholar to access articles from various scientific journals and theses from Sam Ratulangi University and other universities related to the contribution of coconut farming to family income. The data obtained were analyzed using contribution analysis and using descriptive analysis presented in table form. The results showed that the amount of income received by coconut farmers was Rp. 1,837,320. While the contribution of coconut farming to household income is $27.45 \%$. This means that coconut farming provides a moderate contribution and cannot be used as the main source of household income in Klabat Village. ${ }^{* e p r m *}$
\end{abstract}

Keywords: contribution, income, coconut farmers, Klabat Village, Dimembe Sub-district

\section{ABSTRAK}

Penelitian ini bertujuan untuk mengetahui: 1) Besarnya pendapatan rata-rata petani kelapa per kuartal, 2) Besarnya kontribusi usahatani kelapa terhadap pendapatan keluarga per kuartal. Pengumpulan data pada penelitian ini dilaksanakan pada bulan Oktober sampai bulan November 2018 di Desa Klabat, Kecamatan Dimembe Kabupaten Minahasa Utara. Metode yang digunakan adalah metode survei, dengan menggunakan data primer dan data sekunder. Data primer diperoleh melalui wawancara langsung dengan 25 petani kelapa dan satu orang perangkat Desa Klabat berdasarkan daftar pertanyaan yang telah disiapkan sebelumya. Data sekunder dalam penelitian ini bersumber dari toko buku lokal, dan internet melalui google cendekia untuk mengakses artikel dari berbagai jurnal ilmiah dan skripsi dari Universitas Sam Ratulangi serta perguruan tinggi lain yang berkaitan dengan kontribusi usahatani kelapa terhadap pendapatan keluarga. Data yang diperoleh dianalisis menggunakan analisis kontribusi serta menggunakan analisis deskriptif yang disajikan dalam bentuk tabel. Hasil penelitian menunjukkan besarnya pendapatan yang diterima oleh petani kelapa adalah sebesar Rp.1.837.320. Sedangkan kontribusi usahatani kelapa terhadap pendapatan rumah tangga adalah sebesar 27,45\%. Artinya usahatani kelapa memberikan kontribusi sedang dan belum dapat dijadikan sebagai sumber utama pendapatan rumah tangga di Desa Klabat. ${ }^{* e p r m *}$

Kata kunci: kontribusi, pendapatan, petani kelapa, Desa Klabat, Kecamatan Dimembe 


\section{PENDAHULUAN}

\section{Latar Belakang}

Kelapa merupakan komoditas strategis yang memiliki peran sosial, budaya, dan ekonomi dalam kehidupan masyarakat Indonesia. Manfaat tanaman kelapa tidak hanya terletak pada daging buahnya yang dapat diolah menjadi santan, kopra, dan minyak kelapa, tetapi seluruh bagian tanaman kelapa mempunyai manfaat yang besar. Sukamto (2001), menjuluki kelapa sebagai pohon kehidupan, juga menamakannya pohon surga. Kelapa merupakan tanaman tropis yang telah lama di kenal masyarakat Indonesia.

Usahatani kelapa merupakan, kegiatan bercocok tanam yang di lakukan oleh petani mulai dari penyiapan lahan, pemilihan bibit, penanaman, pembersihan lahan, pemupukan/pemberian pestisida, sampai proses produksi dilakukan dimana hasil penjualan produksi digunakan untuk memenuhi kebutuhan hidup.

Karakter usahatani kelapa Indonesia di dominasi oleh perkebunan tanaman kelapa rakyat. Menurut Tarigan (2002), usahatani perkebunan kelapa rakyat mempunyai ciri-ciri sebagai berikut:

1. Luas kepemilikan lahan usahatani sangat sempit

2. Produktivitas usahatani kelapa masih rendah

3. Pendapatan usahatani masih rendah

4. Produktivitas usahatani masih bersifat tradisional yaitu masih dalam bentuk kelapa butiran dan kopra.

Dengan ciri-ciri tersebut, tingkat pendapatan petani menjadi rendah. Salah satu cara untuk meningkatkan pendapatan petani kelapa adalah dengan meningkatkan nilai tambah dari produk yang selama ini di jual oleh petani dalam bentuk kelapa butiran ataupun dalam bentuk kopra menjadi produk minyak kelapa yang di kelola sendiri oleh petani.

Pertanian adalah proses produksi biologis yang di dasarkan pada tumbuh kembang tanaman dan hewan. Tumbuhan merupakan pabrik pertanian primer. Tumbuhan dapat mengambil gas karbondioksida dari udara melalui daunnya, akar tumbuhan menyerap hara dari dalam tanah, selanjutnya dengan memanfaatkan sinar matahari, tanaman melakukan fotosintesis yang menghasilkan biji, buah, serat dan minyak. Petani adalah orang yang mengelola lahan pertanian dan memelihara tanaman guna memperoleh hasil pertanian untuk memenuhi kebutuhan hidupnya.
Sulawesi Utara khususnya di Desa Klabat Kecamatan, Dimembe Kabupaten Minahasa Utara merupakan salah satu desa yang penduduknya sebagian besar melakukan usahatani kelapa, namun masalah yang di hadapi petani saat ini yaitu rendahnya harga jual kelapa butiran dan harga kopra, serta tingginya biaya tenaga kerja. Untuk itu penelitian ini dilakukan untuk mengetahui pendapatan petani kelapa dan besarnya kontribusi usahatani kelapa dalam memenuhi kebutuhan hidup petani.

\section{Penelitian Terdahulu}

Daftar Penelitian terdahulu dapat dilihat pada Tabel 1.

\section{Tabel 1. Daftar Penelitian Terdahulu}

\begin{tabular}{|c|c|c|}
\hline 1. & Nama dan Tahun & $\begin{array}{l}\text { Paulus A. L,Welson M. Wangke, } \\
\text { Dan Vicky R. B. Moniaga. (2015) }\end{array}$ \\
\hline & Judul Penelitian & $\begin{array}{l}\text { Kontribusi usahatani kacang } \\
\text { panjang terhadap pendapatan } \\
\text { rumah Tangga petani di Desa } \\
\text { Warembungan } \\
\text { Pineleng. }\end{array}$ \\
\hline & Tujuan Penelitian & 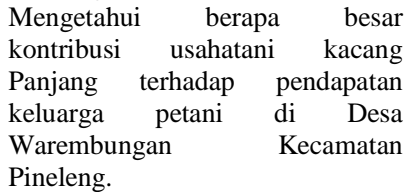 \\
\hline & $\begin{array}{l}\text { Metode yang Digunakan } \\
\text { : }\end{array}$ & $\begin{array}{l}\text { Waktu dan Tempat Penelitian: } \\
\text { Penelitian ini akan dilaksanakan } \\
\text { selama } 3 \text { bulan terhitung bulan Mei } \\
\text { sampai Juli 2015. Penelitian } \\
\text { dilaksanakan di Desa Warembungan } \\
\text { Kecamatan Pineleng. } \\
\text { Metode pengumpulan data: } \\
\text { Metode pengumpulan data dilakukan } \\
\text { dengan Metode sensus. Data yang } \\
\text { digunakan yaitu data primer } \\
\text { Diperoleh melalui wawancara } \\
\text { langsung dengan petani Responden } \\
\text { berdasarkan pertanyaan yang telah } \\
\text { disusun Dalam kuesioner dan data } \\
\text { sekunder diperoleh dari instansi Yang } \\
\text { terkait dengan penelitian ini. } \\
\text { Metode pengambilan sampel: } \\
\text { Penentuan lokasi pengambilan sampel } \\
\text { dilakukan Secara sengaja (purposive } \\
\text { sampling), yaitu di Desa Warembungan } \\
\text { Kecamatan Pineleng. Penelitian ini } \\
\text { diambil berdasarkan jumlah petani yang } \\
\text { mengusahakan Usahatani kacang } \\
\text { panjang, dengan jumlah Petani 20 } \\
\text { orang. Data yang diperoleh dalam } \\
\text { Penelitian ini di analisis secara } \\
\text { deskriptif }\end{array}$ \\
\hline & Hasil Penelitian & $\begin{array}{l}\text { Hasil penelitian menunjukkan bahwa } \\
\text { usahatani kacang panjang dapat } \\
\text { memberikan kontribusi yang cukup bagi } \\
\text { pendapatan keluarga petani di Desa } \\
\text { Warembungan dengan hasil persentase } \\
36.33 \% \text { disetiap tahunnya. Ini berarti } \\
\text { usahatani kacang panjang dapat menjadi } \\
\text { sumber pendapatan petani karena, nilai } \\
\text { pendapatan usahatani kacang panjang } \\
\text { terhadap total pendapatan keluarga } \\
\text { petani dapat memberikan pengaruh } \\
\text { yang cukup baik. }\end{array}$ \\
\hline
\end{tabular}


Tabel Lanjutan Penelitian Terdahulu

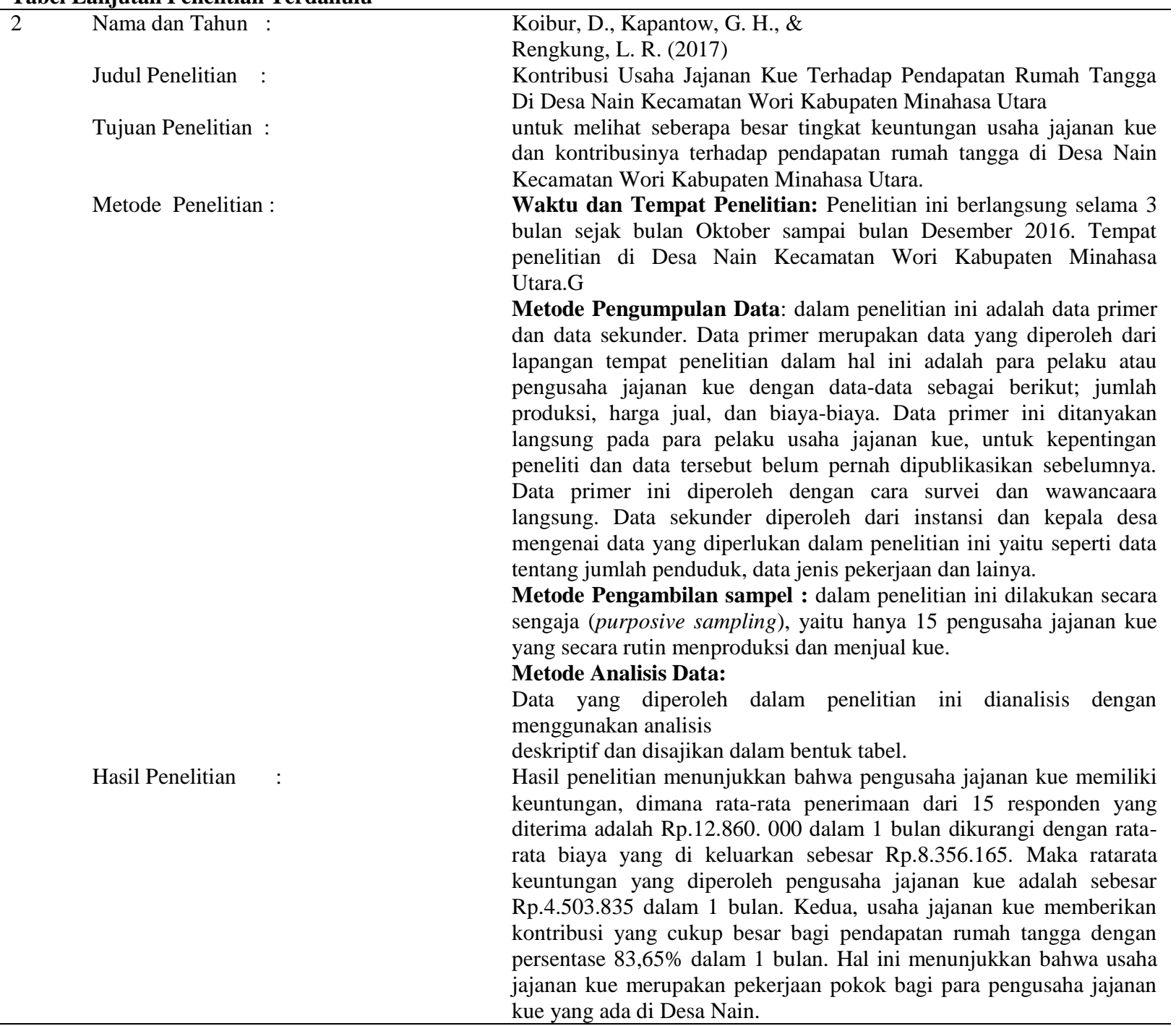


Tabel Lanjutan Penelitian Terdahulu

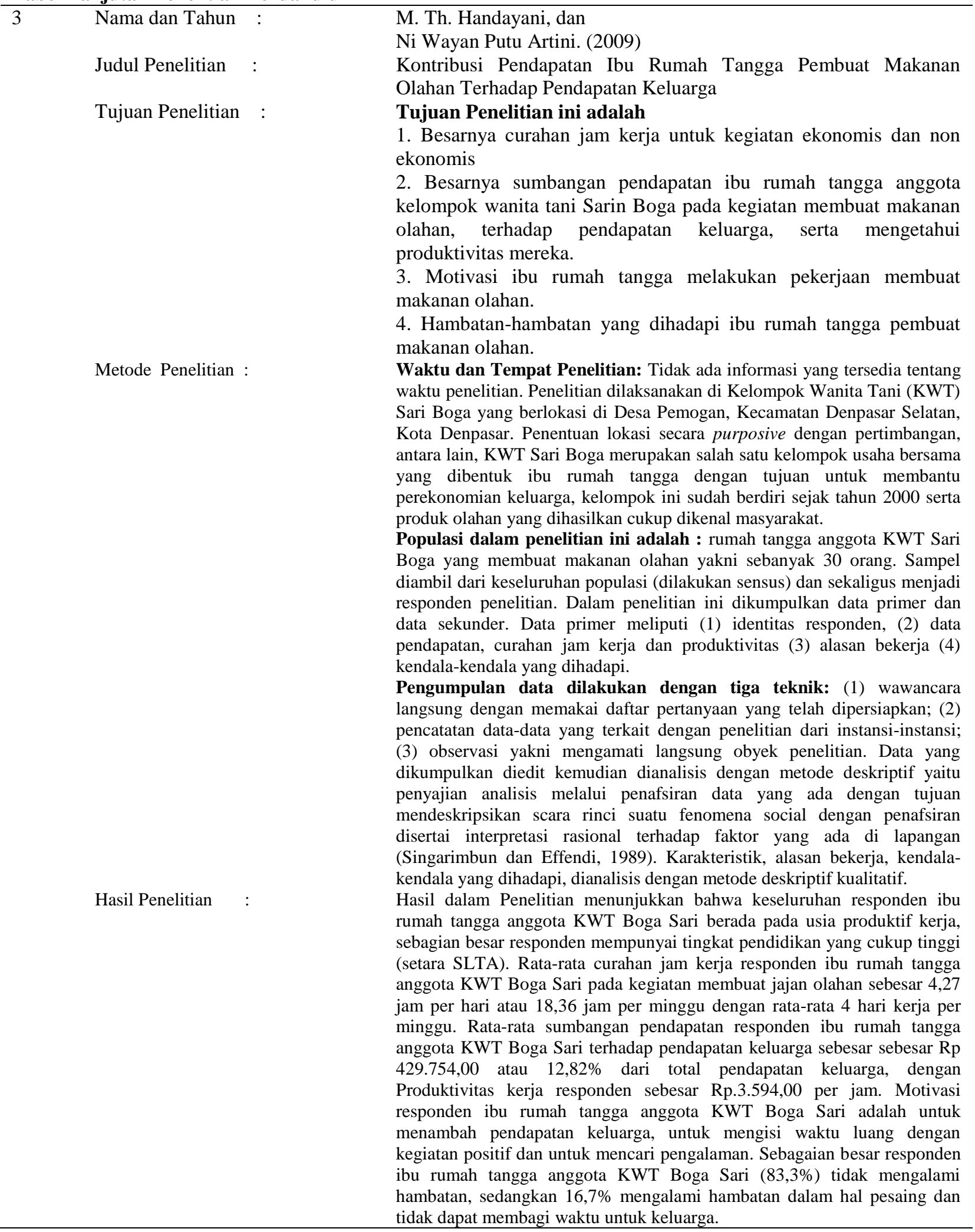




\section{Rumusan Masalah}

Berdasarkan latar belakang yang telah dikemukakan maka yang menjadi permasalahan dalam penelitian ini yaitu:

1. Berapa besarnya pendapatan rata-rata petani kelapa per kuartal (4 bulan)?

2. Berapa besarnya kontribusi usahatani kelapa terhadap pendapatan keluarga?

\section{Tujuan Penelitian}

Penelitian ini bertujuan untuk mengetahui:

1. Besarnya pendapatan petani kelapa rata-rata petani kelapa per kuartal (4 bulan).

2. Besarnya kontribusi usahatani kelapa terhadap pendapatan keluarga.

\section{Manfaat Penelitian}

Penelitian ini bermanfaat bagi peneliti untuk meningkatkan pengetahuan tentang besarnya pendapatan petani dalam usahatani kelapa dan kontribusi usahatani kelapa terhadap pendapatan petani. Sebagai bahan untuk penerus teori dan konsep yang dipelajari peneliti selama pendidikan dan bahan referensi bagi peneliti lainnya. Serta sebagai bahan pertimbangan bagi pemerintah dalam menentukan kebijakan bagi petani.

\section{METODE PENELITIAN}

\section{Lokasi dan Waktu Penelitian}

Penelitian ini dilaksanakan di Desa Klabat, Kecamatan Dimembe Kabupaten Minahasa Utara Pemilihan lokasi berdasarkan kriteria bahwa di Desa Klabat terdapat petani kelapa dengan kepemilikan lahan sendiri serta sebagian besar anggota masyarakat Desa Klabat merupakan petani kelapa. Penelitian ini dilaksanakan pada bulan Oktober sampai bulan November 2018.

\section{Metode Pengumpulan Data}

Metode yang digunakan dalam penelitian ini adalah metode survei, dengan mengunakan data primer dan data sekunder. Data primer diperoleh melalui wawancara langsung dengan responden berdasarkan daftar pertanyaan yang telah disiap sebelumnya. Data sekunder diperoleh dari instansi yang terkait langsung dengan penelitian dalam hal ini kantor Desa Klabat serta telaah pustaka yang berkaitan dengan kontribusi usahatani kelapa terhadap pendapatan keluarga.

\section{Konsep Pengukuran Variabel}

Variabel-variabel yang di ukur sebagai berikut:

1. Karakteristik responden dalam hal ini petani kelapa berupa umur, luas lahan, tingkat pendidikan, pekerjaan, dan biaya tenaga kerja.

2. Pendapatan Petani, Pendapatan petani yaitu: pendapatan petani yang didapat dari hasil pertanian kelapa dikurangi biaya pengeluaran dalam penjualan (tenaga kerja) (Rp/bulan). Biaya yang dihitung hanya biaya yang dikeluarkan untuk pemeliharaan dan biaya panen. Biaya yang dikeluarkan petani sebelumnya seperti biaya penanaman tidak dihitung lagi (sunk cost).

3. Pendapatan dalam keluarga di hitung berdasarkan:

a) Pendapatan suami yaitu pendapatan yang diperoleh dari hasil penjualan kelapa dikurangi biaya pengeluaran dalam pemeliharaan, biaya tenaga kerja dan biaya angkut (Rp/kuartal).

b) Pendapatan istri pendapatan yang diperoleh dari berbagai pekerjaan yang di jalankan, yang dihitung berdasarkan (Rp/bulan).

c) Pendapatan anak yaitu dari anak laki-laki dan perempuan yang belum menikah tapi sudah bekerja yang tinggal serumah dan makan satu pengeluaran ( $\mathrm{Rp} / \mathrm{bulan})$.

\section{Metode Analisis Data}

Analisis data dalam penelitian ini dilakukan secara deskriptif kualitatif untuk menganalisis data dengan cara memaparkan, mengelola, menggambarkan dan menafsirkan hasil penelitian dengan kata-kata dan kalimat sebagai jawaban atas permasalahan yang diteliti, serta mengorganisasi dan menganalisis data. 
Hasil penelitian ini dianalisis secara deskriptif (descriptive analysis) dan di sajikan dalam bentuk tabel. Sedangkan menurut Soekartawi (1995), untuk mengetahui besar penerimaan usahatani kelap dapat di dengan mengunakan rumus :

Dimana :

$$
\mathrm{TR}=\mathrm{Q} \times \mathrm{Pq}
$$

$\mathrm{TR}=$ Total Revenue/total penerimaan

$\mathrm{Q}=$ jumlah produksi yang di jual

$\mathrm{Pq}=$ harga tiap satuan produksi

Sedangkan perhitungan kontribusi Usahatani kelapa terhadap pendapatan keluarga menggunakan rumus:

$$
\text { kontribusi }=\frac{\text { Pendapatan Usahatani Kelapa }}{\text { Total Pendapatan Rumah Tangga }} \times 100 \%
$$

\section{HASIL DAN PEMBAHASAN}

\section{Letak Geografis}

Desa Klabat merupakan salah satu Desa di Wilayah Kecamatan Dimembe, yang terletak di bagian Timur Kecamatan Dimembe Kabupaten Minahasa Utara dan berbatasan dengan Kota Bitung, dibawah kaki Gunung Klabat.

- Ketinggian dari permukaan laut 450 sampai 600 meter.

- Dengan suhu rata-rata 23 sampai dengan 29 derajat celcius.

- Curah hujan tidak menentu.

- Batas Wilayah Desa Klabat:

Utara : Batas Kepolisian Desa Pinilih dan Hutan Mawiau

Timur : Kelurahan Karondoran, Perkebunan Kelurahan Kumersot Kota Bitung

Selatan : Gunung Klabat

Barat : Batas Kepolisian Desa Pinilih

\section{Keadaan Penduduk}

Total keseluruhan jumlah penduduk yang ada di Desa Klabat sebanyak 2491 jiwa, dengan jumlah kepala keluarga $460 \mathrm{KK}$. Dengan demikian jumlah rata-rata anggota per keluarga sebanyak 5 orang.

\section{Sarana dan Prasarana}

Secara umum pembangunan dan perkembangan suatu wilayah ditentukan oleh sumberdaya manusia serta di fasilitasi dengan sarana dan prasarana yang memadai dari wilayah tersebut. Sarana dan prasarana merupakan dua hal yang tidak dapat dipisahkan karena keduanya saling mengisi atau melengkapi (Koibur, dkk, 2017). Sarana dan prasarana yang ada di Desa Klabat yaitu sebagai berikut:

\section{Pendidikan}

Pendidikan merupakan hal yang sangat penting di dalam kehidupan manusia dan pendidikan itu sendiri akan diperoleh setiap orang secara formal maupun non formal. Prasarana pendidikan yang terdapat di Desa Klabat dapat dilihat pada Tabel 1.

\begin{tabular}{lll}
\multicolumn{2}{l}{ Tabel } & 1. Jumlah Gedung Sekolah di Desa Klabat \\
\hline No & Gedung Sekolah & Jumlah Gedung \\
\hline 1 & TK & 1 \\
2 & SD & 3 \\
\hline & Jumlah & 4 \\
\hline
\end{tabular}

\section{Agama}

Setiap orang berhak memilih dan memeluk agama yang merupakan kepercayaan dari setiap orang. Tempat ibadah yang merupakan prasaran yang ada di Desa Klabat dapat dilihat pada Tabel

Tabel 2. Jumlah Tempat Ibadah di Desa Klabat

\begin{tabular}{llc}
\hline No & Tempat Ibadah & Jumlah Gedung \\
\hline 1 & GMIM & 2 \\
2 & GPDI & 1 \\
3 & MESJID & 2 \\
4 & ADVENT & 1 \\
\hline & Jumlah & $\mathbf{6}$ \\
\hline
\end{tabular}

\section{Umur}

\section{Karakteristik Responden}

Kemampuan atau melakukan aktifitas secara fisik bahkan cara berpikir seseorang sangat dipengaruhi oleh faktor umur. Demikian juga dengan para petani dalam melakukan pekerjaannya, petani yang memiliki umur muda tentunya memiliki kondisi fisik yang lebih kuat serta memiliki daya pikir yang lebih kreatif dibandingkan yang berumur tua. Krakteristik responden berdasarkan tingkat umur dapat dilihat dalam Tabel 3. 


Tabel 3. Jumlah Responden Menurut Umur
\begin{tabular}{llcc}
\hline No & Kelompok Umur (Tahun) & Responden & Persentase (\%) \\
\hline 1 & $<49$ & 7 & 28 \\
2 & $50-59$ & 7 & 28 \\
3 & $60-69$ & 4 & 16 \\
4 & $70-79$ & 4 & 16 \\
5 & $>80$ & 3 & 12 \\
\hline & Jumlah & $\mathbf{2 5}$ & $\mathbf{1 0 0}$ \\
\hline
\end{tabular}

Umur responden terendah 33 tahun dan umur tertinggi 82 tahun. Tabel 3 menunjukkan bahwa responden yang berada pada usia dibawah 60 tahun sebanyak 14 responden atau $56 \%$ diikuti dengan kisaran umur 60 tahun sampai 79 sebanyak 8 orang atau $32 \%$ dan umur di atas 80 tahun yang terendah yaitu sebanyak 3 responden atau $12 \%$.

\section{Tingkat Pendidikan}

Peranan pendidikan formal sangat penting dalam usaha peningkatan kualitas seseorang karna berguna dalam pembangunan pribadi serta peningkatan intelektual dan wawasan seseorang. Tingkat pendidikan responden bervariasi mulai dari tingkat sekolah dasar (SD) sekolah lanjutan tingkat pertama (SLTP) sekolah lanjutan tingkat atas (SLTA) sampai akademika. Tingkat pendidikan petani kelapa secara rinci dapat dilihat dalam Tabel 4.

\begin{tabular}{llcc}
\multicolumn{5}{l}{ Tabel } & Jumlah Responden \\
\hline No & Tingkat Pendidikan & Responden & Persentase (\%) \\
\hline 1 & Tidak Tamat SD & 3 & 12 \\
2 & SD & 7 & 28 \\
3 & SLTP & 8 & 32 \\
4 & SLTA & 6 & 24 \\
5 & AKADEMIKA/D3 & 1 & 4 \\
\hline & Jumlah & $\mathbf{2 5}$ & $\mathbf{1 0 0}$ \\
\hline
\end{tabular}

Tabel 4 menunjukkan bahwa tingkat pendidikan responden terdapat kecenderungan semakin tinggi tingkat pendidikan semakin sedikit petani kelapa yang mencapainya. Jumlah responden dengan tingkat pendidikan SLTP kebawah sebanyak 18 orang atau 72 persen.

\section{Luas Lahan}

Luas lahan yang diusahakan petani akan mempengaruhi besarnya pendapatan petani itu sendiri. Apabila semakin besar lahan yang diusahakan oleh petani maka semakin besar pula jumlah produksi dan jumlah pendapatan yang akan dihasilkan. Luas lahan petani kelapa dapat dilahat pada Tabel 5.

\begin{tabular}{|c|c|c|c|}
\hline No & Luas lahan (Ha) & Responden & Persentase (\%) \\
\hline 1 & $<1$ & 3 & 12 \\
\hline 2 & $1-6$ & 21 & 84 \\
\hline \multirow[t]{2}{*}{3} & $>6$ & 1 & 4 \\
\hline & Jumlah & 25 & 100 \\
\hline
\end{tabular}

\section{Pekerjaan responden pada usahatani kelapa dan di luar usaha tani kelapa}

Pekerjaan merupakan bagian yang penting bagi manusia karena dengan bekerja manusia dapat menghasilkan barang atau jasa sehingga segala kebutuhan dapat terpenuhi. Mata pencaharian pokok dan mata pencaharian tambahan responden dapat dilihat dalam Tabel 6.

Tabel 6. Jumlah Responden Menurut Jenis Pekerjaan Usahatani Kelapa dan di Luar Usahatani Kelapa

\begin{tabular}{llcc}
\hline No & Jenis pekerjaan & Responden & Persentase (\%) \\
\hline 1 & Petani kelapa saja & 11 & 44 \\
2 & Petani kelapa dan Wirausaha & 7 & 28 \\
3 & Petani kelapa dan Buruh tani & 5 & 20 \\
4 & Petani kelapa dan Tambang & 1 & 4 \\
5 & Petani dan Pensiunan & 1 & 4 \\
\hline & Jumlah & $\mathbf{2 5}$ & $\mathbf{1 0 0}$ \\
\hline
\end{tabular}

Tabel 6 menunjukkan bahwa responden yang hanya bekerja sebagai petani kelapa sebanyak 11 atau 44\% responden, Petani kelapa yang memiliki pekerjaan sampingan sebagai wirausaha terdiri atas usaha bunga krans (1), cap tikus (1), pedagang pasar lokal (4) dan warung (1) sebanyak 7 atau $28 \%$ responden, petani kelapa yang memiliki pekerjaan sampingan sebagai buruh tani sebanyak 5 atau $20 \%$ responden, petani kelapa yang memiliki pekerjaan sampingan sebagai penambang sebanyak 1 atau $4 \%$ responden, dan petani yang memiliki pekerjaan sampingan sebagai PNS sebanyak 1 atau $4 \%$ responden.

\section{Penerimaan Usahatani Kelapa per kuartal (4 Bulan)}

Penerimaan adalah perkalian antara jumlah produksi yang dihasilkan dengan harga jual produksi per satuannya. Penerimaan Usahatani kelapa yang di peroleh petani kelapa di Desa Klabat berbeda-beda. Hal ini disebabkan karena jumlah pohon kelapa dan jumlah buah/biji kelapa yang dikerjakan tidak sama. Total penerimaan yang diperoleh petani kelapa per kuartal (4 bulan) 
adalah Rp.78.227.500, dengan jumlah ratarata penerimaan yang diterima petani adalah Rp.3.129.100. Penerimaan tertinggi yang diperoleh petani kelapa adalah Rp.9.200.000, dan penerimaan terendah adalah Rp.600.000.

\section{Biaya Produksi per kuartal}

Biaya produksi Usahatani kelapa adalah biaya yang di keluarkan pada saat pelaksanaan Usahatani kelapa dilakukan. Biaya produksi Usahatani kelapa terdiri dari biaya tetap dan biaya variabel.

a. Biaya Tetap Usahatani kelapa

Biaya tetap adalah biaya yang tidak tergantung dari besar kecilnya volume produksi. Biaya tetap Usahatani kelapa terdiri dari biaya pajak dan biaya Tenaga kerja.

b. Biaya Variabel

Biaya variabel adalah biaya yang berubahubah, dalam penelitian ini biaya variabel usahatani kelapa terdiri dari biaya pupuk/pestisida, dan transportasi. Biaya produksi Usahatani kelapa dapat di lihat dalam Tabel 7.

\begin{tabular}{lr} 
Tabel 7. Biaya Produksi Usahatani Kelapa & \\
\hline Biaya produksi & Usahatani Kelapa (Rp) \\
\hline a. Biaya tetap (Rp) & - \\
- Biaya pajak & $32,294,500$ \\
- Tenaga kerja & $32,294,500$ \\
Jumlah Biaya Tetap & - \\
b. Biaya variabel (Rp) & - \\
- Pupuk dan pestisida & \\
- Transportasi & \\
Jumlah Biaya Variabel & $\mathbf{3 2 , 2 9 4 , 5 0 0}$ \\
\hline Jumlah Biaya Produksi &
\end{tabular}

Dari hasil penelitian responden di Desa Klabat hanya mengeluarkan biaya tenaga kerja di sebabkan di daerah penelitian kususnya responden dalam proses produksi tidak mengunakan pupuk/pestisida dan hasil produksi diambil langsung oleh perusahaan sehingga tidak ada biaya transportasi.

\section{Pendapatan Responden per kuartal}

Pendapatan responden yang ada di Desa Klabat dapat di golongkaan menjadi dua bagian yaitu pendapatan Usahatani kelapa dan pendapatan di luar Usahatani. a) Pendapatan Usahatani kelapa

Pendapatan Usahatani kelapa merupakan pendapatan yang di peroleh dari proses produksi Usahatani kelapa/kuartal yang di wujudkan dalam bentuk rupiah. Pendapatan pertanian selama empat bulan dihitung berdasarkan banyaknya panen di kurangi biaya produksi. Pendapatan Usahatani kelapa secara rinci dapat di lihat dalam Tabel 8.

Tabel 8. Rata-rata Pendapatan Usahatani Kelapa per kuartal (4 Bulan) Berdasarkan Luas Lahan

\begin{tabular}{lc}
\hline Keterangan & Nilai \\
\hline Rata-rata luas lahan & 1,67 \\
Rata-rata penerimaan & $3,129,100$ \\
Rata-rata biaya & $1,291,780$ \\
Rata-rata pendapatan & $1,837,320$ \\
\hline
\end{tabular}

Tabel 8 menunjukkan bahwa rata-rata luas lahan responden adalah seluas $1.67 \mathrm{Ha}$ yang di peroleh melalui pembagian antara total luas lahan $41.69 \mathrm{Ha}$ dibagikan dengan jumlah responden yaitu 25 orang, sedangkan rata-rata pendapatan kelapa per petani adalah sebesar Rp.1.837.320 dan rata-rata pendapatan per hektar adalah Rp.1.060.998 yang diperoleh dari total pendapata petani Rp.45.933.000 dibagi dengan total luas lahan $41.69 \mathrm{Ha}$.

b) Pendapatan di luar usahatani kelapa Pendapatan di luar Usahatani kelapa adalah pendapatan yang di peroleh responden selain berusaha sebagai petani kelapa yaitu sebagai buruh dan pedagang dalam kurun waktu satu bulan untuk lebih jelasnya dapat dilihat dalam Tabel 9 berikut ini;

\begin{tabular}{lrrcc}
\multicolumn{4}{l}{ Tabel 9. Pendapatan Diluar Usahatani Kelapa } \\
\hline No & $\begin{array}{r}\text { Pendapatan } \\
\text { (Rp/kuartal) }\end{array}$ & Responden & Persentase (\%) \\
& 0 & 11 & 44 \\
\hline 1 & $2.000 .000-8.000 .000$ & 10 & 40 \\
2 & $>8.000 .000$ & 4 & 16 \\
3 & & $\mathbf{2 5}$ & $\mathbf{1 0 0}$ \\
\hline & Jumlah & & & \\
\hline
\end{tabular}

Pendapatan diluar usahatani kelapa yang dikerjakan oleh petani kelapa pada Tabel 9, menunjukkan bahwa 11 responden dengan persentase $44 \%$ tidak memiliki pekerjaan di luar Usahatani kelapa, sedangkan 10 responden dengan persentase $40 \%$ dan 4 responden dengan persentase $16 \%$ memiliki pendapatan dari non kelapa dan di luar Usahatani kelapa yang berkisar antara Rp.2.000.000 - Rp.8.000.000, dan lebih dari Rp.8.000.000. 


\section{Total Pendapatan Rumah Tangga per kuartal (4 Bulan)}

Total pendapatan rumah tangga responden per kuartal (4 bulan) dan di nyatakan dalam rupiah. Total pendapatan rumah tangga merupakan hasil seluruh pendapatan bersih dari pendapatan usahatani kelapa dan pendapatan di luar Usahatani dapat di lihat pada Tabel 10.

Tabel 10. Total Pendapatan Rumah Tangga per kuartal (4 Bulan)

\begin{tabular}{crrr}
\hline No. & Kelapa & Non kelapa & $\begin{array}{c}\text { Total Pendapatan } \\
\text { Rumah Tangga }\end{array}$ \\
\hline 1 & $1,960,000$ & $6,240,000$ & $8,200,000$ \\
2 & $2,250,000$ & - & $2,250,000$ \\
3 & $1,074,000$ & - & $1,074,000$ \\
4 & 920,000 & $11,200,000$ & $12,120,000$ \\
5 & $2,960,000$ & - & $2,960,000$ \\
6 & $1,160,000$ & $6,160,000$ & $7,320,000$ \\
7 & 855,000 & $10,400,000$ & $11,255,000$ \\
8 & $2,395,000$ & $7,200,000$ & $9,595,000$ \\
9 & $2,000,000$ & $27,400,000$ & $29,400,000$ \\
10 & $1,370,000$ & $6,000,000$ & $7,370,000$ \\
11 & $1,002,500$ & $6,000,000$ & $7,002,500$ \\
12 & $1,770,000$ & $12,000,000$ & $13,770,000$ \\
13 & $-36,000$ & $8,000,000$ & $7,964,000$ \\
14 & 600,000 & - & 600,000 \\
15 & $6,200,000$ & - & $6,200,000$ \\
16 & $-175,000$ & $6,000,000$ & $5,825,000$ \\
17 & 850,000 & - & 850,000 \\
18 & 587,500 & - & 587,500 \\
19 & 400,000 & - & 400,000 \\
20 & $1,450,000$ & $4,800,000$ & $6,250,000$ \\
21 & $5,250,000$ & - & $5,250,000$ \\
22 & $1,700,000$ & - & $1,700,000$ \\
23 & $2,700,000$ & - & $2,700,000$ \\
24 & $4,400,000$ & $2,000,000$ & $6,400,000$ \\
25 & $2,290,000$ & $8,000,000$ & $10,290,000$ \\
\hline Total & $\mathbf{4 7 , 9 3 3 , 0 0 0}$ & $\mathbf{1 1 9 , 4 0 0 , 0 0 0}$ & $\mathbf{1 6 7 , 3 3 3 , 0 0 0}$ \\
\hline Rata-rata & $\mathbf{1 , 9 1 7 , 3 2 0}$ & $\mathbf{4 , 7 7 6 , 0 0 0}$ & $\mathbf{6 , 6 9 3 , 3 2 0}$ \\
\hline & & & \\
\hline
\end{tabular}

Berdasarkan Tabel 10 maka dapat dilihat bahwa total pendapatan rumah tangga responden per kuartal (4 bulan) yaitu Rp.47.933.000. Pendapatan rumah tangga tertinggi adalah Rp.29.400.000 dan pendapatan terendah adalah Rp.400.000. Rata-rata pendapatan rumah tangga adalah Rp.6.693.320 yang diperoleh dari rata-rata pendapatan pertanian Rp.1.917.320 ditambahkan dengan rata-rata pendapatan non-pertanian Rp.4.776.000. Tabel 10 juga menunjukkan bahwa tidak semua responden memiliki pekerjaan sampingan atau pekerjaan di nonpertanian.

\section{Kontribusi dari Usahatani Kelapa Terhadap Pendapatan Rumah Tangga Responden}

Kontribusi yang di maksud dalam penelitian ini adalah sumbangan dari Usahatani kelapa yang di lakukan di daerah penelitian sebanyak 25 responden petani yang berpofesi sebagai petani kelapa. Usahatani kelapa di Desa Klabat di usahakan oleh para petani untuk memperoleh pendapatan. Selain Usahatani kelapa petani di Desa Klabat juga memperoleh pendapatan dari usaha lain yaitu wirausaha, buruh tani, tambang, dan lain sebagainya baik yang di kerjakan oleh kepalah keluarga atau anggota keluarga. Pendapatan total rumah tangga di sini dapat dihitung dari pendapatan Usahatani kelapa dan pendapatan di luar Usahatani kelapa. Untuk menghitung besarnya kontribusi dari Usahatani kelapa terhadap pendapatan keluarga dapat menggunakan rumus dibawa ini. Untuk lebih jelas kontribusi Usahatani kelapa dapat di lihat pada Tabel 11.

$$
\text { Kontribusi }=\frac{\text { Pendapatan Usahatani kelapa }}{\text { Total pendapatan rumah tangga }} \times 100 \%
$$

Tabel 11. Kontribusi Usahatani Kelapa Terhadap Pendapatan Rumah Tangga per kuartal (4 Bulan)

\begin{tabular}{|c|c|c|c|c|}
\hline No & \multicolumn{2}{|c|}{$\begin{array}{l}\text { Sumber } \\
\text { Pendaapatan }\end{array}$} & $\begin{array}{r}\text { Total } \\
\text { Pendapatan } \\
(\mathbf{R p}) \\
\end{array}$ & Kontribusi (\%) \\
\hline 1 & \multicolumn{2}{|c|}{ Usahatani Kelapa } & $45,933,000$ & 27.45 \\
\hline 2 & $\begin{array}{l}\text { Usahatani } \\
\text { Kelapa }\end{array}$ & Non & $2,000,000$ & 1.20 \\
\hline \multirow[t]{2}{*}{3} & $\begin{array}{l}\text { Usaha } \\
\text { Pertanian }\end{array}$ & Non & $119,400,000$ & 71.35 \\
\hline & Jumlah & & $167,333,000$ & 100 \\
\hline
\end{tabular}

Tabel 11 menunjukkan bahwa jumlah pendapatan Usahatani kelapa adalah Rp.45.933.000 dengan kontribusi 27,45\%, jumlah Usahatani non kelapa adalah Rp.2.000.000 dengan kontribusi 1,20\%, sedangkan jumlah pendapatan usaha nonpertanian berjumlah Rp.119.400.000 dengan persentase $71,35 \%$. Usahatani kelapa memiliki kontribusi lebih kecil dibandingkan dengan kontribusi yang diperoleh dari usaha non pertanian. 


\section{KESIMPULAN DAN SARAN}

\section{Kesimpulan}

Berdasarkan penelitian yang dilakukan di Desa Klabat, maka dapat diambil kesimpulan bahwa besarnya pendapatan yang diterima oleh petani kelapa adalah sebesar Rp.1.837.320 Sedangkan kontribusi Usahatani kelapa terhadap pendapatan rumah tangga adalah sebesar $27,45 \%$.

\section{Saran}

Penyuluhan tentang pentingnya pemeliharaan, pemberian bantuan pupuk dan pestisida bagi petani kelapa untuk meningkatkan produksi kelapa selain itu perlu diadakan juga Penyuluhan tentang pengelolaan hasil produksi seperti bagai mana cara pengelolaan kelapa, agar petani memperoleh tambahan pendapatan keluarga.

\section{DAFTAR PUSTAKA}

Anonim, 2019. Gambaran Umum Desa Klabat. Diakses pada http://ldesaklabat.blogspot.com/2014/12/gambaranumum-desa.htm.

Handayani, M. T., dan Artini, N, W. P. 2009. Kontribusi Pendapatan Ibu Rumah Tangga Pembuat Makanan Olahan Terhadap Pendapatan Rumah Tangga, PIRAMIDA Jurnal Kependudukan dan Pengembangan Sumber Daya Manusia. Vol V, No. 1 : Juli 2009. ISSN. 19073275.

Koibur, D., Kapantow, G. H., \& Rengkung, L. R. 2017. Kontribusi Usaha Jajanan Kue Terhdap Pendapatan Rumah Tangga di Desa Nain Kecamatan Wori Kabupaten Minahasa Utara. Agri-Sosioekonomi: Jurnal Ilmiah Sosial Ekonomi Pertanian, 13(2), 69-78.
Paulus, Achelien L., Welson M. Wangke, and Vicky RB Moniaga. "Kontribusi USAhatani Kacang Panjang terhadap Pendapatan Rumah Tangga Petani di Desa Warembungan Kecamatan Pineleng." AGRI-SOSIOEKONOMI 11.3 (2015): 53-62.

Soekartawi. 1995. Agribisnis Teori dan aplikasi. PT. Raja G Grafindo Persada. Jakarta.

Sukamto. 2001. Upaya Meningkatkan Produksi Kelapa. PT. Penebar Swadaya. Jakarta.

Tarigan, D. D. 2002. Sistem Usahatani Berbasis Kelapa. Perspektif, no. 1., vol.1 Puslitbang Perkebunan. Bogor. 